\title{
The Impact of the Eight-Week High-Intensity Interval Training Implemented by the National Track and Field Team on Some Motor Skills by Gender
}

\author{
Serdar Adigüzel \\ Siirt University School of Physical Education and Sports, Siirt, Turkey \\ E-mail: serdaradiguzel@siirt.edu.tr \\ Baykal Karataş (Corresponding author) \\ Ağrı İbrahim Çeçen University School of Sports Science, Ağrı, Turkey \\ E-mail: bkaratas@agri.edu.tr \\ Burak Yücel \\ Ağrı İbrahim Çeçen University School of Sports Science, Ağrı, Turkey \\ E-mail: byucel@agri.edu.tr
}

Received: June 9, 2021 Accepted: June 28, 2021 Published: July 2, 2021

doi:10.5296/jei.v7i1.18736 URL: https://doi.org/10.5296/jei.v7i1.18736

\begin{abstract}
Purpose: This study aims to study the impact of the eight-week high-intensity interval training implemented by the national track and field team on some motor skills by gender.

Technique and method: The study involves 17 male and 16 female athletes ages 18 to 26 who currently pursue an active sports life in the Turkish national crosscountry teams. The anaerobic strength, agility, vertical and horizontal jump values, and sprint skills of the athletes in the study were measured.

Findings: Through statistical assessment, it was found that while there was a significant increase in the Wingate test, it was not significant in terms of gender. It was also found that while significant decreases took place in the right-foot jump, left-foot jump, right-foot vertical jump, left-foot vertical jump, double-foot vertical jump, Illinois agility test, and sprint
\end{abstract}


test values, there were no significant differences based on gender.

Conclusion: The study suggests that an eight-week high-intensity interval training boosts the anaerobic capacities of young female and male national cross country athletes and improve performance parameters such as jump and vertical jump performance, agility, and sprint.

Keywords: Athlete, Motoric feature, HIIT

\section{Introduction}

Athletics, the core of the Olympic Games, is considered to bring significant contributions to basic athletic stamina as well as to motoric features. Athletics has also been reported to improve the cardiovascular and respiratory systems. In addition, it appears to enhance basic motoric features such as speed, strength, stamina, dexterity, and dynamism in children and have positive effects on the physical development of individuals in adolescence (Biçer, 2009).

Athletic games among women are similar to those among men. The Heptathlon for women or the Decathlon for men is the events combining running, jumping, and throwing races. Cross country running and races and road running races are regarded as the types of training running people in the athletics sport engage in outside the season. Running, which is part of athletics, refers to races against other competitors and against time over various pre-defined distances.

Athletics is believed to be the oldest of all sports branches and one of the ones attracting the greatest interest. It is divided into two main categories: track running and road running. Track running is based on the principle of covering a given distance at the fastest speed. All running is measured using a time measurement device called "a chronometer" (Yapıc1 \& Ersoy, 2015).

In athletics, athletes use several training techniques to ensure the development of motoric features. Many researchers seem to have generated a number of variables that can be used in determining the exercise intensity of athletes doing endurance training (Sjodin et al., 1982; Hill, 1993; Billat, 2001; Revan et al., 2008). If the trainings used to improve VO2max and their impact are investigated, it appears that quite a number of methods and practices are available. It was found that high-intensity interval training is primarily effective in boosting endurance performance (Lindsay et al., 1996; Laursen \& Jenkins, 2002; Smith et al., 2003). In addition, the method of interval training, which is decisive in terms of stamina and other physiological parameters, ensures repeated use of the ATP-PC stocks. This provides sufficient stimuli in the energy capacity of the ATP-PC system and helps relieve muscle fatigue since anaerobic glucose is not used in a large amount. Regular adjustment of the exercise time and the rest period ncreases and improves anaerobic glucose maximally. In interval studies containing resting with long duration, many repetation and short pause, oxygen carrying system becomes difficult and increases in aerobic system.

HIIT İs a training method useful in boosting an athlete's performance and increasing his or her capacity level. Interval training is also a type of workout where low-intensity exercises or full rest periods are scattered between short repetitions made above the lactate threshold or 
the peak speed/strength. The relevant literature suggests high-intensity interval training to be a method which allows athletes to go through less strain or to engage in more comprehensive workout. Consequently, this property of high-intensity interval training can reduce stress and help manage time and can allow for more stimuli to accumulate than in other forms of exercise. This type of training helps meet the particular requirements of this sports branch and sustain high-intensity stimuli with less physiological strain (Laursen \& Buchneit, 2019).

Research shows that HIIT, which has recently become popular, can improve aerobic capacity, anaerobic capacity, and simultaneous metabolic functions over a two-week period of six workout sessions (Barker et al., 2014). It is appealing since, compared to conventional workout programs, it uses time with higher economy and efficiency and boosts aerobic and anaerobic capacity, metabolic functions, and physical performance (Bayati et al., 2011; Greeley et al., 2013).

Following previous research, this study examined the changes due to HIIT in some physical motoric features of a group of female and male national athletes who have won acclaim in international competitions.

\section{Material Method}

The study involves 16 male and 15 female national cross country athletes with at least a Balkan championship who all volunteered to participate. They were first informed about the scope of the study in detail. They were then asked to indicate whether they would like to participate, and if so, to sign a form of consent. The participants who were in the training group implemented a high-intensity interval training program three days a week in addition to the regular training for their individual branch. The pretest and posttest measurements of the athletes were carried out at Ataturk University Laboratory of Physical and Physiological Test Measurement. In addition, an approval was obtained from Ağrı İbrahim Çeçen University Scientific Research Ethics Board on 30.04.2021.

\subsection{Research Design}

The study lasted eight weeks, and the participants implemented HIIT three days per week during this time. The human body can adjust to training programs neurologically and physiologically, and this holds valid for the variability of many parameters. The human body adjusts some of its motoric features in 2 to 6 weeks, and it has been reported that after the body reaches a certain level, improvement in aerobic and anaerobic capacity follows (Sucjomel et al., 2018; Del Vecchio et al., 2019). Horizontal jump test, Wingate anaerobic test, single- and double-foot jump test, single- and double- vertical jump test, Illinois agility test, and sprint test values were obtained from the participants at the beginning and at the end of the study.

\subsection{Training Program}

The participants in the training group implemented a HIIT on three days of the week and continued the regular training for their individual branches on the other days. The workout session, which lasts for about 1 hour and 15 minutes, involves a 15-minute warm-up at the 
beginning and a 15-minute cool-down at the end. The training program was sustained at a medium level over a period of 8 weeks.

The HIIT implemented by the national crosscountry athletes over 8 weeks is demonstrated in Table 1 below.

Table 1.8 weekly HIIT

\begin{tabular}{|l|l|l|l|}
\hline Movement & Duration & Number of Repetitions & Rest \\
\hline $10 \times 400$ & - & 10 & Productive rest $1 / 3$ \\
\hline Sprint run & $30 \mathrm{~m}$ & 10 & 10 seconds \\
\hline High Jumping & 30 seconds & - & 10 seconds \\
\hline Reverse Crunch & 10 seconds & 10 & 10 \\
\hline Jumping Jacks & 30 seconds & - & 10 seconds \\
\hline High Knees Running in place & 30 seconds & - & 10 seconds \\
\hline Squat Jumping & 30 seconds & - & 10 seconds \\
\hline Touch toes & - & 15 & 10 seconds \\
\hline Lunges & - & 10 & 10 seconds \\
\hline Butt Kicks & - & 25 meters & 10 seconds \\
\hline
\end{tabular}

\subsubsection{Vertical Jump Test}

The vertical jump test measurements of the participants were conducted using the smart jump vertical jump measuring mat of a Smart Speed brand device. The participants stepped on the jumping mat in their athletic clothes and shoes. They were asked to jump on the mat as high as they could after squatting down at $90^{\circ}$ degrees with their hands at their waist and standing on both feet (Loturco et al., 2020). Each participant was given two rounds and the chance to take a rest of up to 3 minutes between the rounds for maximum performance. The higher value was recorded as his or her vertical jump.

\subsubsection{Wingate Anaerobic Strength and Capacity Test}

The Wingate anaerobic strength test was conducted using a mechanic ergometer connected to a computer (Monark Ergomedic 984 E, Pike Byke, Finland). After they were informed about the test in detail, the subjects were asked to warm up for 5 minutes at a 60 to $70 \mathrm{~W}$ workload. A load that is equivalent to $7.5 \%$ of the BW of every subject was determined and placed on the basket of the bicycle. The saddle height was adjusted, and their feet was fixed to the pedals using clips. The subjects were asked to reach the maximal pedal speed in 3 or 4 seconds before the application of the load, and then the load on the basket was taken and the 
resistance from the weight was directed to the pedals. They were asked to sustain the pedal speed for 30 seconds once the test started. The subjects were motivated verbally during the test. This test was only held once. The instant peak power (IPP) (the highest power recorded in the initial 5 seconds), the anaerobic power (ANP) (the average power in the initial 5 seconds), and the anaerobic capacity (ANC) (the average power measured over the 30 seconds) were calculated through computer software. The fatigue index (FI) was calculated using the formula FI $=$ [(First 5-second power - Last 5-second power $) /$ First 5-second power $]$ $\times 100$ involving the average power values recorded during the first and last five seconds.

\subsubsection{Illinois Agility Test}

The test racetrack, which was $5 \mathrm{~m}$ in width and $10 \mathrm{~m}$ in length and consisted, in the middle, of three cones placed on a flat line with a 3.3 distance between them, was installed inside an indoor sports hall with a synthetic floor. The test consisted of a slalom run, $40 \mathrm{~m}$ of which was flat, and $20 \mathrm{~m}$ was between the cones, and which involved $180^{\circ}$ turns at every 10 meters. Two gate photocell electronic chronometer systems with 0.01 -second sensitivity (Tümer Elektronik Ltd., Turkey) were placed at its start and finish. The subjects were introduced to the racetrack and given the necessary instructions prior to the test, and they were then allowed to run 3 to 4 trials at a slow pace. Following this step, the subjects were asked to make warm-up and stretching exercises at a slow pace they chose for 5 to 6 minutes. The subjects exited the test racetrack at its start line in face-down position and with their hands touching the ground at the shoulder level. The racetrack finish time was recorded in terms of seconds. The test was run once only.

\subsubsection{0 m Sprint Test}

The repeated anaerobic sprint test consists of $10 \times 30$ meters along with a 10 -second test between every two sprints. The Newtest 300 (Finland) test battery was used to determine the repeated sprint test skills of the participants. The start photocell started measuring as soon as the athletes began their race 1 meter behind it, and the finish photocell recorded the distance run in terms of horizontal jump test.

\subsubsection{Horizontal Jump Test}

Splash test data and device setup were performed in accordance with the recommendations of the company that produced the device. Optojump is widely used in vertical and horizontal jump tests and reliability studies have been carried out. In this test, the athletes were asked to jump to the determined horizontal direction targets by keeping their hands free, knees in full extension and the body in an upright position with the maximum possible speed. Athletes made 3 trials with right, left and double feet each and the best performance was recorded. Jump data were taken as right foot, left collar and double foot. Pulling the knees during the flight portion of the jump was recorded as an incorrect move (Santos at al., 2014).

\subsection{Statistical Analysis}

The SPSS 22.00 program operating on Windows 10 was used to analyze the data obtained in the study. Repeated Measures ANOVA analysis was used to examine the sex variation in the 
variables obtained from the female and male athletes during the pretest and posttests, and the level of significance was found to be $p<0.05$.

\section{Findings}

The national athletes participating in the study were analyzed as the high-intensity interval training group. The data obtained through the analysis were presented as pre-training and post-training within the training group.

Table 2. Repeated measurements ANOVA analysis results for the comparison of the measurement results of the national athletes in the study

\begin{tabular}{|c|c|c|c|c|c|}
\hline Measurement & Sex & Pretest & Posttest & p (time) & $p($ time $\times$ sex $)$ \\
\hline \multirow{2}{*}{ Horizontal } & Female & $1422.02 \pm 538.75$ & $1535.5 \pm 573.69$ & \multirow{2}{*}{.182} & \multirow{2}{*}{.796} \\
\hline & Male & $1505.01 \pm 637.47$ & $1582.09 \pm 550.6$ & & \\
\hline \multirow{2}{*}{ Wingate aneorobic test average power } & Female & $531.42 \pm 151.31$ & $646.33 \pm 134.73$ & \multirow{2}{*}{.000} & \multirow{2}{*}{.134} \\
\hline & Male & $527.58 \pm 109.23$ & $602.93 \pm 112.61$ & & \\
\hline \multirow{2}{*}{ Horizontal right foot } & Female & $334.67 \pm 173.47$ & $260.87 \pm 130.19$ & \multirow{2}{*}{.004} & \multirow{2}{*}{.197} \\
\hline & Male & $220 \pm 98.58$ & $190.38 \pm 59.12$ & & \\
\hline \multirow{2}{*}{ Horizontal jump left foot } & Female & $340.2 \pm 184.11$ & $243.13 \pm 109.65$ & \multirow{2}{*}{.000} & \multirow{2}{*}{.574} \\
\hline & Male & $346.69 \pm 174.82$ & $271.81 \pm 124.83$ & & \\
\hline \multirow{2}{*}{ Horizontal jump double-foot } & Female & $330.47 \pm 177.16$ & $249.27 \pm 106.32$ & \multirow{2}{*}{.000} & \multirow{2}{*}{.535} \\
\hline & Male & $372.75 \pm 209.98$ & $312.38 \pm 193.22$ & & \\
\hline \multirow{2}{*}{ Vertical jump right foot } & Female & $652.53 \pm 225.09$ & $516.4 \pm 195.01$ & \multirow{2}{*}{.000} & \multirow{2}{*}{.090} \\
\hline & Male & $862.56 \pm 294.77$ & $781.81 \pm 258.51$ & & \\
\hline \multirow{2}{*}{ Vertical jump left foot } & Female & $674.73 \pm 180.87$ & $543.73 \pm 173.68$ & \multirow{2}{*}{.000} & \multirow{2}{*}{.558} \\
\hline & Male & $873.06 \pm 395.78$ & $761.94 \pm 338.56$ & & \\
\hline \multirow{2}{*}{ Vertical jump double-foot } & Female & $656.8 \pm 221.16$ & $522.27 \pm 202.3$ & \multirow{2}{*}{.000} & \multirow{2}{*}{.057} \\
\hline & Male & $752.13 \pm 266$ & $700 \pm 216.24$ & & \\
\hline \multirow{2}{*}{ Illinois agility test } & Female & $26.0 \pm 1.69$ & $24.4 \pm 1.43$ & \multirow{2}{*}{.000} & \multirow{2}{*}{.287} \\
\hline & Male & $26.51 \pm 1.54$ & $25.45 \pm 1.32$ & & \\
\hline \multirow{2}{*}{$30 \mathrm{~m}$ sprint test } & Female & $4.52 \pm 0.22$ & $4.43 \pm 0.27$ & \multirow{2}{*}{.004} & \multirow{2}{*}{.360} \\
\hline & Male & $4.27 \pm 0.28$ & $4.09 \pm 0.17$ & & \\
\hline
\end{tabular}


An analysis of Table 2 reveals that there is no significant variation over time between the pretest and posttest values of the horizontal jump measurements $(p>0.05)$ and that the time $\times$ sex variation is not statistically significant $(\mathrm{p}<0.05)$. The Wingate test results show that while a significant increase took place between the pretest and the posttest $(p<0.05)$, the time $\times$ sex variation is not statistically significant $(p>0.05)$. In the right foot jump, left foot jump, right foot vertical jump, left foot vertical jump, double-foot vertical jump, Illinois test, and sprint test scores, it appears that while there took place a significant decrease by time between the pretest and the posttest $(p<0.05)$, the time $\times$ gender variation is not statistically significant $(\mathrm{p}>0.05)$.

\section{Discussion}

This study investigated whether an eight-week HIIT impacted the jump, vertical jump, sprint speed, agility, and anaerobic performance of young national athletes.

HIIT which has become popular in recent years since it yields better results in improving aerobic capacity, anaerobic capacity, physical fitness, and body composition than other types of exercise, has been reported to be appealing to more people and to bring about change in shorter time than moderate-intensity workout (Sperlich et al., 2011). HIIT, which is implemented in athletics and other sports branches, has been found to improve the speed performance of athletes (Akılveren, 2018; Gökkurt, 2019; Howard \& Stavrianeas, 2017; Sperlich et al., 2011; Wong et al., 2010). The contemporary literature emphasizes that high-intensity interval workout is one of the effective training methods used by athletes to boost physical performance and metabolic activities (Gibala \& Mcgee, 2012). The capacity of athletes to adjust their movements, overcome physical limitations, change direction with speed, and preserve body position depends on their level of agility (Asadi, 2012; Günay \& Ş1ktar, 2017). Other studies indicate that high-intensity interval workout impacts agility performance and thus parallel the findings in our study.

High-intensity interval training has been reported to produce more muscle fiber and to boost both aerobic and anaerobic capacity since it stimulates the cardiovascular and respiratory systems (Karp, 2000; Gillen et al., 2010; Gharah et al., 2014). To illustrate, Aykor and Dönmez (2017) applied the method of high-intensity interval training for 24 athletes. Their results indicate a significant increase in the anaerobic capacity of the athletes. Another, similar study reports that 30 sedentary males ages 17 to 25 achieved a significant increase in their anaerobic strength values by engaging in high-intensity interval training three days a week over a period of six weeks (Gürbüz, 2013). Sajedi (2017) found a significant differentiation between the averages of the Wingate pretest and posttest working groups, which parallels the conclusion from our research. While many researchers argue that high-intensity interval training generally targets aerobic capacity, other authors claim that it boosts both aerobic and anaerobic capacity (Arazi et al., 2017; Howard \& Stavrianeas, 2017).

Canacan (2014) identified the elements of successful athletic performance as leg muscle power and vertical jump performance. As an example of this, in a study on elite young athletes, Kobal et al. (2017) found a significant increase in the dynamic power and vertical jump levels at the end of various combinations of interval training. Anıl et al. (2011) showed 
based on their pretest and posttest results that an eight-week training program is effective in terms of vertical and horizontal jumps, $30 \mathrm{~m}$ sprint speed performance, elasticity, and body intensity, leading to improvements. The tests conducted as part of our study overlap with their vertical jump and sprints tests; however, while Anıl (2001) found a significant increase in horizontal jump performance, our study identified no such change.

In conclusion, the HIIT program was found to have enhanced the anaerobic capacity of the young national athletes and to have improved their athletic performance level, which involves motoric features such as vertical jump performance, agility, and speed. Nevertheless, it can be suggested that this training program has no effect on the horizontal jump level and that this might be related to the duration and method of training. An analysis of Table 2 reveals that there is no significant variation over time between the pretest and posttest values of the horizontal jump measurements $(\mathrm{p}>0.05)$ and that the time $\times$ sex variation is not statistically significant $(\mathrm{p}<0.05)$. The Wingate test results show that while a significant increase took place between the pretest and the posttest $(\mathrm{p}<0.05)$, the time $\times$ sex variation is not statistically significant $(p>0.05)$. Furthermore, it is possible to argue that the high-intensity interval training is economic in terms of time and should be part of the training programs for other sports branches. The results indicate that the jumping properties of the athletes who make the group of athletes significantly improved both in women (right foot pretest: $334.67 \pm 173.47 \mathrm{~cm}$; right foot posttest: $260.87 \pm 130.19 \mathrm{~cm}$; left foot pretest: $340.2 \pm 184.11 \mathrm{~cm}$; left foot posttest: $243.13 \pm 109.65 \mathrm{~cm}$; double-foot pretest: $330.47 \pm 177.16 \mathrm{~cm}$; double-foot posttest: $249.27 \pm 106.32 \mathrm{~cm} ; \mathrm{p}<0.05$ ) and in men (right foot pretest: $220 \pm 98.58 \mathrm{~cm}$; right foot posttest: $190.38 \pm 59.12 \mathrm{~cm}$; left foot pretest: $346.69 \pm 174.82 \mathrm{~cm}$; left foot posttest: $271.81 \pm 124.83 \mathrm{~cm}$; double foot pretest: $372.75 \pm 209.98 \mathrm{~cm}$; double-foot posttest: $312.38 \pm 193.22 \mathrm{~cm} ; \mathrm{p}<0.05)$ at the end of eight weeks, but that no significant differences in performance were found between the sexes. The results also show that at the end of the eight-week high-intensity interval training, the vertical jump scores of both women (right foot pretest: $652.53 \pm 225.09 \mathrm{~cm}$; right foot posttest: $516.4 \pm 195.01 \mathrm{~cm}$; left foot pretest: $674.73 \pm 180.87 \mathrm{~cm}$; left foot posttest: $543.73 \pm 173.68 \mathrm{~cm}$; double-foot pretest: $656.8 \pm 221.16$ $\mathrm{cm}$; double-foot posttest: $522.27 \pm 202.3 \mathrm{~cm} ; \mathrm{p}<0.05$ ) and men (right foot pretest: $862.56 \pm 294.77 \mathrm{~cm}$; right foot posttest: $781.81 \pm 258.51 \mathrm{~cm}$; left foot pretest: $873.06 \pm 395.78$ $\mathrm{cm}$; left foot posttest: $761.94 \pm 338.56 \mathrm{~cm}$; double foot pretest: $752.13 \pm 266 \mathrm{~cm}$; double-foot posttest: $700 \pm 216.24 \mathrm{~cm} ; \mathrm{p}<0.05)$ improved, but that no differences surfaced in relation to the sex factor. The test results suggest that a rise took place in the anaerobic performance of both female (Wingate pretest: $531.42 \pm 151.31 \mathrm{~W}$; Wingate posttest: $646.33 \pm 134.73 \mathrm{~W}$; p < 0.05 ) and male (Wingate pretest: $527.58 \pm 109.23 \mathrm{~W}$; Wingate posttest: $602.93 \pm 112.61 \mathrm{~W} ; \mathrm{p}<$ $0.05)$ athletes in the study. Moreover, the agility and sprint test results suggest that both female (agility pretest: $26.0 \pm 1.69 \mathrm{~s}$; agility posttest; $24.4 \pm 1.43 \mathrm{~s}$; sprint pretest; $4.52 \pm 0.22 \mathrm{~s}$; sprint posttest: $4.43 \pm 0.27 \mathrm{~s} ; \mathrm{p}<0.05$ ) and male (agility pretest: $26.51 \pm 1.54 \mathrm{~s}$; agility posttest: $25.45 \pm 1.32 \mathrm{~s}$; sprint pretest: $4.27 \pm 0.28 \mathrm{~s}$; sprint posttest: $4.09 \pm 0.17 \mathrm{~s} ; \mathrm{p}<0.05$ ) athletes displayed improvement in their performance.

The eight-week high-intensity interval training program was found to have no impact on the horizontal jump performance of either female (horizontal jump pretest: $1422.02 \pm 538.75 \mathrm{~cm}$; 
horizontal jump posttest: $1535.5 \pm 573.69 \mathrm{~cm}$; $\mathrm{p}<0.05$ ) or male (horizontal jump pretest: $1505.01 \pm 637.47 \mathrm{~cm}$; horizontal jump posttest: $1582.09 \pm 550.6 \mathrm{~cm} ; \mathrm{p}<0.05)$ athletes and not to lead to a sex difference.

\section{References}

Ak1lveren, E. (2018). Futbolda Yüksek Şiddetli Interval Antrenman ve Tekrarlı Sprint Antrenmanlarının Aerobik Performans Üzerine Etkisinin İncelenmesi (Akdeniz Üniversitesi Sağlık Bilimleri Enstitüsü. Yüksek Lisans Tezi).

Anıl, F., Erol, E., \& Pulur, A. (2001). Pliometrik Çalışmaların 14-16 yaş Grubu Bayan Basketbolcuların Bazı Fiziksel ve Fizyolojik Parametreleri Üzerine Etkisi. Gazi Beden Eğitimi ve Spor Bilimleri Dergisi (Gazi BESBD), VI(2), 19-26.

Arazi, H., Keihaniyan, A., Eatemadyboroujeni, A., Oftade, A., Takhsha, S., Asadi, A., \& Ramirez-Campillo, R. (2017). Effects of Heart Rate vs. Speed-Based High İntensity İnterval Training on Aerobic and Anaerobic Capacity of Female Soccer Players. Sports, 5(3), 57. https://doi.org/10.3390/sports5030057

Asadi, A. (2012). Effects of Six Weeks Depth Jump and Counter Movement Jump Training on Agility Performance. Roudbar Branch Islamic Azad University, Roudbar, Iran. Sport Science, 5, 67-70.

Aykora, E., \& Dönmez, E. (2017). Kadın voleybolcularda tabata protokolüne göre uygulanan pliometrik egzersizlerin kuvvet parametrelerine etkisi. Journal of Bitlis Eren University Institute of Social Sciences, 6(1), 71-84.

Barker, A. R., Day, J., Smith, A., Bond, B., \& Williams, C. A. (2014). The influence of 2 weeks of low-volume high-intensity interval training on health outcomes in adolescent boys. J Sports Sci, 32(8), 757-765. https://doi.org/10.1080/02640414.2013.853132

Bayati, M., Farzad, B., Gharakhanlou, R., \& Agha-Alinejad, H. (2011). A practical model of lowvolume high-intensity interval training induces performance and metabolic adaptations that resemble 'all-out' sprint interval training. Journal of Sports Science \& Medicine, 10(3), 571-576.

Biçer, M. A. (2009). Atletizmde Müsabaka Öncesi Mistik Geleneksel Dini İnanışlar ve Rahatlama Yöntemleri VE (p. 45). Ankara/Yenimahalle, Türkiye.

Billat, V. (2001). Interval Training for Performance: A Scientific and Empirical Practice. Sports Med., 31, 13-31. https://doi.org/10.2165/00007256-200131010-00002

Canavan, P. K., \& Vescovi, J. D. (2004). Güç Tahmini Denklemlerinin Değerlendirilmesi: Kadınlarda Pik Dikey Atlama Gücü. Med Sci Spor Egzersizleri, 36, 1589-93. https://doi.org/ 10.1249/01.MSS.0000139802.96395.AC

Fox, E. L., Bowers, R. W., \& Foss, M. L. (1988). Beden Eğitimi ve Sporun Fizyolojik Temelleri (pp. 358-366). Mesut Cerit, Bağırgan Yayınları, Ankara.

Gharah, D. N., Kordi, M. R., \& Gaeini, A. A. (2014). The effect of 4-week high intensity 
interval aerobic training VO2max, TMAX, VO2max of Iranian club soccer players. Biol. Exerc. Sci., 17, 47-57.

Gibala, M. J., \& McGee, S. L. (2012). Physiological Adaptations to Low-Volume, Highİntensity İnterval Training in Health and Disease. $J$ Physiol, 59, 1077-1084. https://doi.org/10.1113/jphysiol.2011.224725

Gillen, J. B., Percival, M. E., Skelly, L. E., Martin, B. J., Tan, R. B., Tarnopolsky, M. A., \& Gibala, M. J. (2014). Three minutes of all-out intermittent exercise per week increases skeletal muscle oxidative capacity and improves cardiometabolic health. PloS One, 9(11). https://doi.org/10.1371/journal.pone.0111489

Gökkurt, K. (2019). U19 Futbolcularda 8 Haftalık Yüksek Yoğunluklu Interval Antrenmanın Sürat, Çeviklik ve İvmelenme Üzerine Etkisi (Selçuk Üniversitesi Sağlık Bilimleri Enstitüsü Yüksek Lisans Tezi).

Greeley, S. J., \& Martinez, N. (2013). Campbell bi the impact of high-intensity interval training on metabolic syndrome. Strength \& Conditioning Journal, 35(2), 63-65. https://doi.org/10.1519/SSC.0b013e31827764da

Günay, M., \& Şıktar, E. (2017). Antrenman Bilimi. Gazi Kitapevi Tic. Ltd. Şti., Ankara.

Gürbüz, M. H. (2013). 17-22 yaş grubu genç erkeklerde 6 haftalık maksimal kuvvet antrenmanının fiziksel fizyolojik parametreler üzerine etkileri. Yüksek Lisans Tezi, Konya

Hill, D. W. (1993). The Critical Power Concept: A Review. Sports Med., 16, 237-254. https://doi.org/10.2165/00007256-199316040-00003

Howard, N., \& Stavrianeas, S. (2017). In-Season High-İntensity İnterval Training İmproves Conditioning in High School Soccer Players. International Journal of Exercise Science, 10, 713.

Iacono, A. D., Eliakim, A., \& Meckel, Y. (2015). Improving Fitness of Elite Handball Players: Small-Sided Games vs. Highİntensity İntermittent Training. The Journal of Strength \& Conditioning Research, 29, 835-43. https://doi.org/10.1519/JSC.0000000000000686

Karp, J. R. (2000). Interval training for the fitness professional. Strength \& Conditioning Journal, 22(4), 64. https://doi.org/10.1519/00126548-200008000-00021

Laursen, P. B., \& Jenkins, D. G. (2002). The Scientific Basis for High-Intensity Interval Training. Sports Med., 32, 53-73. https://doi.org/10.2165/00007256-200232010-00003

Laursen, P., \& Buchheit, M. (2019). Science and Application of High-Intensity Interval Training (pp. 17-73). Champaign, Human Kinetics. https://doi.org/10.5040/9781492595830

Lindsay, F. H., Hawley, J. A., Myburgh, K. H., Schomer, H. H., Noakes, T. D., \& Dennis, S. C. (1996). Improved Athletic Performance in Highly Trained Cyclists after Interval Training. Med. Sci. Sports Exerc., 28, 1427-1434. https://doi.org/10.1097/00005768-199611000-00013

Revan, S., Balcı, Ş. S., Hamdi, P. E. P. E., \& Aydoğmuş, M. (2008). Sürekli ve İnterval Koşu 


\section{Macrothink}

Antrenmanlarının Vücut Kompozisyonu ve Aerobik Kapasite Üzerine Etkileri. Spormetre Beden Ĕ̈itimi ve Spor Bilimleri Dergisi, 6(4), 193-197. https://doi.org/10.1501/ Sporm_0000000112

Sajedi, H. (2017). Glutamine supplementation and anaerobic power outputs of handball players. Gazzetta Medica Italiana Archivio per le Scienze Mediche, 176(1-2), 41-9.

Santos-Lozano, A., Gascón, R., López, I., \& Garatachea-Vallejo, N. (2014). Comparison of two systems designed to measure vertical jump height. RICYDE Revista Internacional de Ciencias del Deporte, 10(36), 123-30. https://doi.org/10.5232/ricyde2014.03603

Sjodın, B., \& Svedenhag, J. (1992). Oxygen Uptake During Running as Related to Body Mass in Circumpubertal Boys: A Longitudinal Study. Eur. J. Appl. Physiol. Occup. Physiol., 65(2), 150-7. https://doi.org/10.1007/BF00705073

Smith, T. P., Coombes, J. S., \& Geraghty, D. P. (2003). Optimizing High-Intensity Treadmill Training Using the Running Speed at Max-Imal $\mathrm{O}_{2}$ Uptake and the Time for Which This Can Be Maintained. Eur. J. Appl. Physiol., 89, 337-343. https://doi.org/10.1007/s00421-0030806-6

Sperlich, B., De Marées, M., Koehler, K., Linville, J., Holmberg, H. C., \& Mester, J. (2011). Effects of 5 Weeks of High-İntensity İnterval Training vs. Volume Training in 14-Year-Old Soccer Players. The Journal of Strength Conditioning Research, 25, 1271-8. https://doi.org/ 10.1519/JSC.0b013e3181d67c38

Wong, P. L., Chaouachi, A., Chamari, K., Dellal, A., \& Wisloff, U. (2010). Effect of Preseason Concurrent Muscular Strength and High-İntensity İnterval Training in Professional Soccer Players. The Journal of Strength Conditioning Research, 24, 653-60. https://doi.org/10.1519/JSC.0b013e3181aa36a2

Yapıc1, K., \& Ersoy, A. (2015). Modern Olimpiyat Oyunlarında Atletizm Rekorların Hazırlayan Faktörler (pp. 1-18). Retrieved from http://dergipark.gov.tr/download/ article-file/55285

\section{Copyright Disclaimer}

Copyright for this article is retained by the author(s), with first publication rights granted to the journal.

This is an open-access article distributed under the terms and conditions of the Creative Commons Attribution license (http://creativecommons.org/licenses/by/3.0/). 